\title{
KOCAELI’NDE EĞíTIM
}

\author{
(1950-1960)
}

\begin{abstract}
Bilal TUNÇ*
ÖZ

Kocaeli'nde 1950 'den itibaren eğitim alanında büyük gelişmeler olmuş ve vilâyet genelinde eğitimin yaygın hale getirilmesi için önemli adımlar atılmıştır. Eğitimin yaygınlaştırılması kapsamında, vilâyete bağlı merkez, ilçe ve köylere yeni okul binaları inşa edilmiş ve okur-yazar oranı ciddi bir biçimde arttırılmıştır. 1950'den itibaren ilkokul, ortaokul, lise ve enstitü sayıları arttığı için öğretmen ve öğrenci sayılarında önceki yıllara oranla büyük artışlar olmuştur. Kocaeli'nde 1950'li yıllarda kız ve erkek enstitüleri gibi meslek okulları dışında lise düzeyinde eğitim veren tek kurum İzmit Lisesi'dir ve bu lise İzmitlilerin yaşamında mühim bir yer tutmaktadır. $\mathrm{Bu}$ çalışmada, 1950'lerde Kocaeli genelindeki okulların, öğretmenlerin ve öğrencilerin sayısal verileri dışında mesleki eğitim kurumları konusu da ele alınmıştır. Başta Devlet İstatistik Enstitüsü verileri olmak üzere yerel basın ile araştırma ve inceleme eserlerinden istifade edilerek hazırlanan bu makalede Kocaeli’ndeki eğitim alanındaki gelişmeler kapsamlı bir biçimde incelenmiştir.
\end{abstract}

Anahtar Kelimeler: Eğitim, Okul, Kocaeli, Okuryazar.

\section{EDUCATION IN KOCAELI}

(1950-1960)

\begin{abstract}
In Kocaeli, there have been major developments in education since 1950 and significant steps were also taken to make education more widespread throughout the province. Within the scope of education dissemination, new school buildings were built in the center, towns and villages of the city and thus, literacy rate significantly increased. Since the number of elementary, secondary, high schools and institutes increased since 1950, there had been a significant increase in the number of teachers and students compared with the previous years. Except for the vocational schools like female and male institutes, Izmit High School was the only high school in Kocaeli in 1950s and this school has an important place in the life of people in İzmit. In addition to the numerical data regarding the schools, teachers and students in Kocaeli in the 1950s, vocational education institutions were also discussed in this study. Primarily based on the data obtained from the State Statistics Institute and Archival documents and by making use of the local press and research and investigation works, the developments in the field of education in the Kocaeli have been extensively investigated in this paper.
\end{abstract}

Keywords: Education, Kocaeli, Literate, School.

* Dr., Sakarya Üniversitesi Sosyal Bilimler Enstitüsü, SAKARYA. burakeylul2205@gmail.com 


\section{Giriş}

Demokrat Parti (DP), kuruluş döneminden başlamak üzere eğitim faaliyetlerine önem vermiş ve bunu hem kuruluş beyannamesinde hem de hükümet programlarında açıkça belirtmiştir. Partinin kuruluş programındaki "Eğitim İşleri” başlığı altında şu görüşler yer almaktadır: Eğitim sisteminde, "Milli Ĕgitim ve Öğretim Birliği’” temel alınmalıdır. Ĕgitimin amacı, gelecek kuşakların yalnız bilimsel ve teknik bilgiyle değil, milli ve insani bütün manevi değerlerle donatılması gereklidir. Ayrıca ilköğretim maarif sisteminin temelidir ve bütün ilkokul öğretmenlerinin aynı ruh ve seviyede temel bilgiye sahip olmaları esasının göz önünde tutulması, bunlar arasında farklı zümrelerin oluşumuna meydan verilmemesi başat olmalıdır. ${ }^{1}$ Tevhid-i Tedrisat'1 savunur görünen bu yaklaşımla DP, Cumhuriyet'in kuruluşundan beri Türkiye'nin önemli eğitim kurumlarından köy enstitülerine karş1 olduğunu, köy ve kentlerde görev yapan öğretmenlerin aynı kaynaktan yetişmeleri gerektiği fikrini üstü kapalı da olsa dile getirmiştir. Hükümete göre, orta tahsil kurumları, gerek program ve talimatname gerek laboratuvar ve kütüphane gibi öğretim vasıtaları bakımından ıslah ve takviyeye muhtaçtı. Bunun dişında liseler yükseköğretime bir basamak olarak görülmüş ve adı geçen eğitim kurumların bu amacı sağlayacak düzeye getirilmesi hedeflenmiştir. ${ }^{2}$

Demokrat Parti kadrolarının eğitim görüşlerinde bütün hükümetlerin kurucusu Adnan Menderes'in görüşleriyle bir paralellik söz konusudur. Özellikle manevi çizgilerden ayrılmamakla beraber bütün bakanların eğitim alanındaki icraatları görevde kaldıkları süreyle paralel düşünülmelidir. Bakanların eğitim görüşlerinin genel olarak milliyetçilik, maneviyat, demokratlık, bilimsellik, faydacılık, laiklik ve ilerleme ilkeleriyle paralel bir şekilde ilerlediğini söylemek mümkündür. Bakanların üzerinde en çok durdukları eğitim sorunları ise; öğretmen yetiştirme, ilköğretim, yükseköğretim, mesleki teknik eğitim, din eğitimi ve halk eğitimidir. ${ }^{3}$

1950'li y1llarda mesleki ve teknik öğretimin, ekonomide benimsenen liberalizm prensibine göre daha etkin bir hale getirilmesi için planlamalar yapılmıştır. Çeşitli derecelerdeki teknik eğitimi yurdun her tarafına yayma çalışmaları, eğitim ve öğretim cihazının ekonomik kalkınmada da vazife alması bakımından önemli sayılmış ve bu çalışmaların ekonomik ihtiyaçlara göre düzenlenmesi öngörülmüştür. Yükseköğretim konusunda DP, üniversitelerin ilmi ve idarî muhtariyete sahip olması gerektiği fikrinde olmuş ve

\footnotetext{
Demokrat Parti Tüzük ve Programı, Ankara 1949, s.59-60.

Zehra Taşdöven, Demokrat Parti Dönemi Eğitim Anlaylşı (1950-1960), Adnan Menderes Üniversitesi Sosyal Bilimler Enstitüsü, (Basılmamış Yüksek Lisans Tezi), Aydın 2013, s.34.

3 Zafer Tangülü, Demokrat Parti Döneminin İlköğretim Politikalart (1950-1960), Firat Üniversitesi Sosyal Bilimler Enstitüsü, (Basılmamış Yüksek Lisans Tezi), Elazı̆̆ 2008, s.43.
} 
muhtelif ilim şubelerinde çalışmak üzere, üniversite içinde, araştırma enstitüleri kurulması ve memlekete ait araştırmalara bilhassa önem verilmesi hususunu vurgulanmıştır. DP'ye göre devletin başlica görevlerinden birisi ilmin, tekniğin, güzel sanatların hızla gelişmesini sağlamak için bütün araç ve tedbirlere başvurmak; kütüphaneler, müzeler, tiyatrolar, konservatuarlar kurmak, ciddi yayında bulunmak, Türk dilinin ulus bünyesine amade bir biçimde hızla gelişmesini sağlamak gibi ulusal ve insani kültür seviyesini yükselmesini sağlayacak her türlü gelişme ve çalışma desteklenmelidir. Devrin hükümeti, kabiliyeti ve akla uygun olan bir ilkokul öğretmeninin eğitim derecelerini tamamlayarak, üniversite profesörlüğüne kadar yükselmesine yasal olanak verileceğini; Doğu Anadolu Bölgesi'nde her yerde okulların açılacağını ve bunları tamamlayan fakülte ve enstitülerin kurulacağını, böylece burada bir kültür merkezi yaratılacağını belirtmiştir. ${ }^{4}$

DP, ülke genelinde okur-yazar oranının sayısını arttırmayı hedeflediği için ilköğretime önem vermiştir. Hükümetin ilköğretimde belirlediği hedef, okulu olmayan köylere okul yapmak, eğitim kalitesini yükseltmek ve yeni bir ilköğretim kanunu hazırlamak olmuştur. 1950 ila 1960 arasındaki dönemde okullaşma oranlarında izlenen politika çerçevesinde köylerde, ilkokulların sayısında yıldan yıla dikkat çeken artışlar görülmüştür. Türkiye'de 1950 yılında Milli Eğitim Bakanlığına bağlı faal bütün özel ve resmi okulların sayıs1 17.927'dir. 1950'den itibaren her yıl düzenli bir artışla bu rakam 1959-1960 yıllarında 22.774'e yükselmiştir. Bu artışın aynısı öğretmen sayılarında da olmuştur. 1949-50 döneminde ülke genelinde 13.339'u kadın, 34.214'ü erkek olmak üzere toplam 47.553 öğretmen yapmaktadır. 1959-60 y1llarında ise 21.334 kadın ve 55.122 erkek olmak üzere toplamda 76.456 öğretmen bulunmaktadır. Aynı şekilde 1950'de 1.758.260 olan öğrenci sayısı 1960'ta 3.023.894'e çıkmıştır. Bu rakamlar devrin iktidarının okulların yaygınlaştırılması politikasının belirli bir başarı seviyesine ulaştığının göstergesidir. ${ }^{5}$

\section{0'den Önce Kocaeli'nde Eğitim}

XIX. yüzyılın sonlarında İzmit Sancağında 222'si Müslüman, 23'ü gayrimüslim okulu olmak üzere toplamda 245 okul bulunmaktadır. Cumhuriyet'in ilanından sonra da bu okullardan 185 'i yeniden kullanılmıştır. $1925^{\prime}$ ten itibaren mevcut okullara ek olarak 89 adet ilkokul daha inşa edilmiş ve 40 köy okulunun binaları da yeniden yaptırılmıştır. Bilhassa Adapazarı, Geyve, Gebze, Karamürsel, Hendek, Karasu, Kandıra ve Gölcük

4 Emre Kılıç, Demokrat Parti Dönemi Milli Eğitim Politikasl, Anadolu Üniversitesi Sosyal Bilimler Enstitüsü, (Basılmamış Yüksek Lisans Tezi), Eskişehir 2008, s. 47.

5 Zehra Arslan, "Demokrat Parti Döneminde Trabzon'da Eğitim", Karadeniz İncelemeleri Dergisi,11/11, 2015, s.108-109. 
ilçelerinde teknik yönden donanımlı okullar vücuda getirilmiştir. $\mathrm{Bu}$ bağlamda, Cumhuriyet'in ilk yıllarında Kocaeli'nde yeni okul yapılmasına ya da mevcut olanların tamir edilmesine örnek İzmit'teki Ulu Gazi İlkokulu'nun tamir edilerek on bir dershaneli ve tam teçhizatlı bir eğitim kurumu haline getirilmesi verilebilir. ${ }^{6}$

Kocaeli'nde Cumhuriyet'ten sonra okullaşma ve okuryazar oranı hızlı bir gelişme göstermiştir. Özellikle vilâyet dâhilinde okuryazarlık, her dönem Türkiye ortalamasının üstünde olmuştur. Bu durum, eğitim faaliyetlerini de önemli ölçüde etkilemiştir. ${ }^{7}$ Özden Senem Binici'ye göre, kentin her anlamda modernleşmesinde eğitimin katkısı yadsınamaz. Bu nedenle kentte tek lise olan İzmit Lise'sinin istenen zamandan daha geç yapılması değişim dönemini ertelemiştir. Daha sonraları İzmit Lisesi'nin açılması ile İzmit Ortaokulu, Kız Sanat Enstitüsü, Ulugazi İlkokulu ve Yeni Turan İlkokulu 1950'lere kadar "merkez" olarak adlandırabileceğimiz alanda eğitim veren ilkokul ve ortaokullar konumunda bulunmuşlardır. ${ }^{8}$

1923 'ten sonra Kocaeli'nde eğitim kurumları artmasına rağmen; vilâyette hem personel hem de teknik bakımdan büyük eksiklikler vardı. Örneğin 1923-1924 Eğitim-Öğretim Dönemi'nde vilâyet genelinde sadece 261 ilkokul öğretmeni bulunmaktadır. Mevcut öğretmenlerin bir kısmı da eğitimci olma kabiliyetinden yoksunlardı. Bu nedenle öğretmen kadrosunu çağdaş bir hale getirmek için kapsamlı çalışmalar yapılmış ve akabinde 1944 yılında öğretmen kadrosu modern eğitim ve terbiye görmüş 567 öğretmenden müteşekkil hale getirilmiştir. Bu dönemde öğretmen sayılarında olduğu gibi öğrenci sayılarında da ciddi artışlar görülmüştür. Örneğin 1923'te ilkokullarda sadece 10.672 öğrenci mevcut iken; bu sayı 1940'ta 18.878'e yükselmiştir. $\mathrm{Bu}$ dönemde vilâyet dâhilinde kadınların eğitimine ağırlık verilmiş ve okula devam eden kadın öğrencilerin sayısının erkek öğrenci sayısıyla aynı olmasına özen gösterilmiştir. Bu durum Kocaeli'nde eğitim faaliyetlerinin gelişme içinde olduğunu göstermesi açısından anlamlıdır. Ayrıca 1945 yılı itibarıyla İzmit'te 151 okul binası mevcut olup; bunların 25'i kentlerde ve 126'sı bucak ve köylerde yer almaktadır. 1950'den itibaren ise Kocaeli'nde eğitim-öğretim alanında daha büyük gelişmeler yaşanmıştır. $\mathrm{Bu}$ anlamda, eğitim ve öğretimdeki ilerlemelerin, Kocaeli’nin gelişmesinde ve önemli bir bilim- kültür merkezi durumuna gelmesinde etkili olduğu düşünülmektedir. ${ }^{9}$

\footnotetext{
6 Rifat Yüce, Kocaeli Tarih ve Rehberi, Kocaeli 1952, s.158.

7 “Kocaeli”, Yurt Ansiklopedisi Il İl Türkiye, Dünü, Bugünü, Yarını, C: VII, İstanbul 1983, s.5055.

8 Özden Senem Binici, İmit'te 1936-1966 Yllları Arasındaki Yapı Üretiminin Kentin Gelişimine Etkileri, Kocaeli Üniversitesi, Fen Bilimleri Enstitüsü, (Basılmamış Yüksek Lisans Tezi), Kocaeli 2012, s.16.

9 Yüce, Kocaeli Tarih ve Rehberi, s. 158-159, 289-291.
} 


\section{0’li Yıllarda Kocaeli’nde Eğitim}

1950'lerde Kocaeli Mili Eğitim Müdürü Şefik Ergündüz'dür. Onun döneminde Kocaeli dâhilinde çok sayıda okul yaptırılmış, öğretmenlerle öğrencilerin sayıları \% 100 arttırılmıştır. DP'den önce Kocaeli'nde birçok okul eğitim hizmetlerine sunulmuş, ancak eğitimi daha da kaliteli hale getirmek amacıyla yeni hükümet tarafindan mevcut okulların sayısı sürekli arttırılmıştır. Böylece adı geçen yeni okulların faaliyete geçmesiyle vilâyette eğitimin daha canlı ve etkin bir duruma geldiği söylenebilir. 1950-1960 arasındaki 10 yıllık süreçte yeni anaokulları, ilkokullar, ortaokullar ve liseler inşa edilmiş, fakat herhangi bir yükseköğretim kurumu yapılmamıştır. ${ }^{10}$

\section{İlkokullar}

DP'nin ilköğretimde belirlediği en önemli hedef, ilköğretimi tüm ülkeye özellikle de okulu olmayan köylere götürebilmek, ilköğretimin kalitesini yükseltmek ve yeni bir ilköğretim kanunu hazırlamaktı. ${ }^{11} \mathrm{Bu}$ nedenle DP devrinde sadece Kocaeli'nde değil ülke genelinde ilkokul sayılarında büyük artışlar olmuştur. Bu kapsamda, Kocaeli'ndeki ilkokul sayılarının artış oranlarını göstermek için tablolardan istifade edilmiştir. Aşağıdaki birinci tabloda DP döneminden önce ve DP devrinde yapılan okul sayılarını kıyaslamak amacıyla sadece1950 ve 1960 'taki ilkokulların sayıları gösterilmiştir.

Tablodan da anlaşılacağ 1 üzere DP döneminde Kocaeli'nde ve 1954'te Kocaeli'nden ayrılan kazaların tamamında okul sayılarında büyük artışlar vardır. 1950'de 158 olan tüm ilkokulların sayıs1 1960'ta 292; 1950'de 230 olan şehir merkezlerindeki okul sayıları ise 1960'ta 309'a çıkmıştır. Ayrıca 1950 'de toplamda 368 olan ilkokulların sayıs1, 1960 itibarıla 601'dir. Yani DP devrinde Kocaeli'ndeki ilkokulların sayısı ortalama iki kat büyüme göstermiştir. Bu da hükümetin eğitim ve öğretime verdiği önemi göstermektedir.

10 Bilal Tunç, Demokrat Parti Döneminde Kocaeli (1950-1960), Sakarya Üniversitesi Sosyal Bilimler Enstitüsü, (Basılmamış Doktora Tezi), Sakarya 2016, s.278.

11 Tunay Karakök, “ Menderes Döneminde (1950-1960) Türkiye’de Eğitim”, Yüksekögrretim ve Bilim Dergisi, 1 / 2, 2011, s.93. 
Tablo 1: 1950 ile 1960 Yılları Arasında Kocaeli’ndeki İlkokulların Sayıları (Sakarya vilâyeti kurulmadan önce)

\begin{tabular}{|l|c|c|c|c|}
\hline İlkokullar & \multicolumn{2}{|c|}{1950} & \multicolumn{2}{c|}{ 1960 } \\
\hline İlçeler & $\begin{array}{c}\text { Köy } \\
\text { Okulları }\end{array}$ & $\begin{array}{c}\text { Şehir İçi } \\
\text { Okullar }\end{array}$ & $\begin{array}{c}\text { Köy } \\
\text { Okulları }\end{array}$ & $\begin{array}{c}\text { Şehir İçi } \\
\text { Okullar }\end{array}$ \\
\hline İzmit & 25 & 31 & 34 & 36 \\
\hline *Adapazar1 ${ }^{12}$ & 36 & 39 & 47 & 45 \\
\hline *Akyazı & 18 & 21 & 29 & 29 \\
\hline Gebze & 11 & 18 & 16 & 20 \\
\hline *Geyve & 21 & 31 & 53 & 57 \\
\hline Gölcük & 5 & 8 & 9 & 10 \\
\hline *Hendek & 13 & 25 & 31 & 32 \\
\hline Kandıra & 13 & 23 & 31 & 32 \\
\hline Karamürsel & 8 & 17 & 21 & 24 \\
\hline *Karasu & 8 & 17 & 21 & 24 \\
\hline Toplam & 158 & 230 & 292 & 309 \\
\hline
\end{tabular}

Bunun dişında 1954'te Sakarya vilâyetinin teşekkül etmesi ile Kocaeli'ndeki ilkokulların sayısı yarı yarıya azalmıştır. Konuya açıklık getirmek açısından Kocaeli’nde kalan İzmit, Karamürsel, Gebze, Kandıra ve Gölcük kazalarındaki okul sayıları aşağıdaki tabloda ayrı gösterilmiştir. ${ }^{13}$

Tablo 2: 1950 ile 1960 Yılları Arasında Kocaeli’ndeki İlkokulların Sayıları (Sakarya vilâyeti kurulduktan sonra)

\begin{tabular}{|l|c|c|c|c|}
\hline İlkokullar & \multicolumn{2}{|c|}{1950} & \multicolumn{2}{c|}{1960} \\
\hline İlçeler & $\begin{array}{c}\text { Köy } \\
\text { Okulları }\end{array}$ & $\begin{array}{c}\text { Şehir İçi } \\
\text { Okullar }\end{array}$ & $\begin{array}{c}\text { Köy Okul } \\
\text { Sayısı }\end{array}$ & $\begin{array}{c}\text { Şehir İçi } \\
\text { Okul Sayısı }\end{array}$ \\
\hline İzmit & 25 & 31 & 34 & 36 \\
\hline Gebze & 11 & 18 & 16 & 20 \\
\hline Gölcük & 5 & 8 & 9 & 10 \\
\hline Kandıra & 13 & 23 & 31 & 32 \\
\hline Karamürsel & 8 & 17 & 21 & 24 \\
\hline Toplam & 62 & 97 & 111 & 122 \\
\hline
\end{tabular}

12 *Bu işaretler, Kocaeli'nden ayrılan ve Sakarya vilâyetine bağlanan ilçeleri ifade etmektedir.

13 DİGM, Milli Eğitim İstatistikleri İlköğretim (1950-1951), Ankara 1951, s.57-58; DİGM, Milli Ĕgitim İstatistikleri İlkögretim (1953-1960), Ankara 1961, s.66, 84. 
Tablodan da anlaşılacağı üzere, beş kazanın Kocaeli'nden ayrılması ile okul sayılarında büyük azalmalar meydana gelmiștir. Bu durum, vilâyetin hem nüfus hem de alan bakımından küçülmesinin doğal bir sonucudur. $\mathrm{Bu}$ veriler DP'nin iktidara geldiği 1950 ile DP'nin son dönemi olan 1960 yıllarını kapsamaktadır. Şimdi de ara dönemdeki yılların verileri üzerinde duracağız:

1950-1951 döneminde Kocaeli genelindeki 365 ve 1951-1952 döneminde 373 okulun 26's1 şehir merkezindedir. ${ }^{14} 1951$ yılında Kocaeli'nde en fazla ilkokulun bulunduğu Adapazarı'nda şehir merkezinde 7, köylerinde 72 olmak üzere 79, Kocaeli Merkez ilçesinde 7'si şehir merkezinde 50'si köylerde olmak üzere 57 ilkokul vardır. Diğer ilçelerde ise ilkokulların adetleri şu şekildedir: Akyazı 29, Gebze 25, Geyve 47, Gölcük 14, Hendek 35, Kandıra 39, Karamürsel 22 ve Karasu 26'dır. Bu dönemde ilçelerin 10'nun da şehir merkezlerinde okul bulunmasına rağmen; Geyve'de şehir merkezinde ilkokul bulunmamaktadır. ${ }^{15}$

1951-192 ders y1lında Kocaeli'nde toplam 307 ilkokul vardır ve bu ilkokullarda 236'sı kadın ve 416'sı erkek olmak üzere 652 öğretmen görev yapmaktadır. ${ }^{16} \mathrm{Bu}$ öğretmenlerin eğitim durumları şu şekildedir: Öğretmenlerden sadece 1'i üniversite ya da yüksekokul mezunudur. Bunun dışında 651 öğretmenin 5'i kadın, 6'sı erkek olmak üzere 11'i ilkokul, 16's1 erkek, 28'i kadın olmak üzere 44'ü ortaokul mezunu, 184'ü erkek 118'i kadın olmak üzere 302'si öğretmen okulu, 30'ü erkek 218'i kadın 238'i köy enstitüsü ve son olarak da 5'i kadın ve 1'i erkek 6'sı lise mezunudur. Ayrıca Kocaeli ilkokul öğretmenlerinden 28'i de ücretli olup Köy Enstitüsü mezunudur. ${ }^{17}$ İstatistikî verilerden açık bir şekilde görülebileceği üzere Kocaeli'ndeki öğretmenlerin büyük bir bölümü öğretmen okulları mezunudur. Ayrıca öğretmenler arasında ilkokul mezunlarını da yer almaktadır.1951-1952 Eğitim-Öğretim Dönemi'nde ise Kocaeli’ndeki 307 ilkokulda 22.370'i erkek ve 13.976'sı kadın olmak üzere toplamda 36.346 ilkokul öğrencisi bulunmaktadır. Bu öğrencilerden 2.507'si erkek ve 1.224'ü kadın toplamda 3.731 kişi mezun olarak ilkokul diplomasını almıştır. ${ }^{18}$

1950’li yıllarda Kocaeli’nde okul, öğretmen ve öğrenci sayıları sürekli olarak yükselme eğilimi içinde olmuştur. Buna göre, 1953-1954 EğitimÖğretim Dönemi'nde 273'ü şehir merkezlerinde ve 466'sı köylerde olmak üzere toplamda 739 ilkokul öğretmeni bulunmaktadır ve bunların tamamı

14 DİGM, İlköğretim İstatistikleri (1950-1951), s.59; DİGM, Milli Eğitim İstatistikleri Ilköğretim (1951-1952), Ankara 1953, s.59.

15 DíGM, İlköğretim İstatistikleri (1951-1952), s.59

16 DİGM, 1953 İstatistik Yıllığı, Ankara 1954, s.139.

17 DİGM, Milli Eğitim İstatistikleri İlkögretim (1951-1952),s.326.

18 DİGM, Milli Ĕ̊̆itim İstatistikleri İlköğretim (1953-1960), s.341. 
kadrolu öğretmenlerdir. Bu kadrolu öğretmenler dışında ilkokullarda görev yapan 63 eğitmen de bulunmaktadır. Söz konusu öğretmen ve eğitmenlerin eğitim durumları ise şu şekildedir: Öğretmenlerin 26's1 ilkokul ve 54'ü ortaokul mezunudur. Öğretmenler arasında en büyük grubu 577 kişi ile öğretmen okulu mezunları oluşturmaktadır. Öğretmen okulu mezunlarını ise 183 kişiyle Köy Enstitüsü mezunları takip etmektedir. Bunun dışında öğretmenler arasında üniversite mezunu sadece bir kişi vardır. ${ }^{19}$

Kocaeli'nde 1950 ile 1960 arasındaki dönemde itibaren yapılan veya tamir edilen ilkokullardan bazıları şunlardır: 1950'de Geyve kazasının Pamukova nahiyesinde 65.000 Türk Lira ile bir okul yaptırılmış ve sonraki dönemlerde Geyve İlkokulu'na ek olarak bir de ortaokul ilave edilmiştir. ${ }^{20}$ İzmit'te 1952'nin ortalarında yapımına başlanan bir ilkokul 1953 yılı içinde tamamlanmış ve eğitim-öğretim hizmetlerine sunulmuştur. ${ }^{21} 21$ Mart 1953 'te İzmit'te Mehmetalipaşa Mahallesi'nin okul ihtiyacını karşılamak amacıyla bir ilkokulun temelleri atılmıştır. Başta Vali olmak üzere birçok kişinin katıldığı törende devrin Milli Eğitim Müdürü Şefik Ergündüz de hazır bulunmuş ve bir konuşma yapmıştır. Milli Eğitim Müdürü'nden sonra vali Ethem Yetkiner de nutuk irat etmiş ve eğitimin öneminden bahsetmiştir. ${ }^{22}$ Adı geçen okul 1955 'te eğitim-öğretime hazır hale getirilmiştir. 1953 yıl1 içerisinde Kocaeli'nde Okulu bulunmayan köylerde eğitim ve öğretim kurumlarının oluşturulması için çalışmalar yapılmıştır. Bu kapsamda çok sayıda köylerde ilkokul mektepleri açılmıştır. Bilhassa tüm ilçelerde köy okullarının sayısının arttırılmasına yönelik faaliyetlere hız verildiği için bütün buralarda okuma yazma bilen insanların sayısında büyük artışlar olmuştur. ${ }^{23} \mathrm{Bu}$ durum 1950'li yıllarda eğitim-öğretimin hızlı bir şekilde geliştiğini göstermektedir.

1953 'te Derince'de 500 öğrencinin eğitim gördüğü bir ilkokul mektebi bulunmaktadır, ancak mahallenin nüfusu sürekli arttı̆g için mevcut okul ihtiyaçları karşılamaz duruma gelmişti. $\mathrm{Bu}$ durumdan dolayı vatandaşlar arasında şikâyetler artmış ve yeni bir okulun açılması için mahalle halkı tarafından vilâyete başvuru yapılmıştı. ${ }^{24}$ Devrin gazetelerine göre, vatandaşların bu talepleri doğrultusunda Derince' de bir ilkokul daha açılması için valilik tarafından birtakım faaliyetler yürütülmüştür. 1953'te İzmit' in Baç Mahallesi'nde yeni bir okul açmak amacıyla Kocaeli Milli Eğitim Müdürlüğü’nce gerekli planlamalar yapılmış ve inşasına 1953'ün Haziran ayı içerisinde başlanan ilkokula Kocaeli'nin kurtuluş tarihinden dolayı 28 Haziran İlkokulu

19 DİGM, Milli Eğitim İstatistikleri İlköğretim (1953-1960), s.224.

20 ATOM, Sinop, Sakarya, İzmit, Edirne, Tekirdağ, İstanbul 1958, s.158-159.

21 Türk Yolu, 13 Mart 1953, No: 4431.

22 Türk Yolu, 22 Mart 1953, No: 4439.

23 Türk Yolu, 10 Eylül 1953, No: 4580.

24 Türk Yolu, 20 Haziran 1953, No: 4514. 
adı verilmiştir. Vilâyet Daimi Encümeni tarafından verilen bu karar, Milli Eğitim Bakanlığı tarafından da tasvip edilmiştir. ${ }^{25}$ İnşaat çalışmaları biten ilkokulda 12 Ocak 1954 'te eğitim-öğretim faaliyetleri başlamıştır. ${ }^{26}$

Kocaeli'nde eğitim ve öğretimi daha kaliteli hale getirmek amaciyla inşa edilen çok sayıda okullar dışında başka faaliyetler de yürütülmüştür. Bunlardan birisi vilâyette okuma yazma sayısını arttırmak amacıyla bazı okullara yeni kitaplıkların tesis edilmesidir. Bu kapsamda İzmit Ulugazi İlkokulu'nda bir kitaplık açılmıştır. Devrin gazetelerine göre, burası gibi diğer ilkokullarda da kitaplıklar oluşturulmuştur. ${ }^{27}$ Söz konusu kitaplıklar sayesinde ilkokullardaki kitap sayılarının arttığı ve öğrencilerle öğretmenlerin daha fazla kitaptan yararlanma imkânına sahip olmaya başladıkları şeklinde düşünülebilir.

1955-1956 Eğitim Öğretim Dönemi’nde idari alandaki düzenlemelerden dolayı Kocaeli genelinde okul sayıları görece çoğalmıştır. Yukarıda ifade olunduğu gibi Kocaeli’ne bağlı beş ilçe olan Adapazarı, Hendek, Akyazı, Karasu ve Geyve ilçelerinden oluşan Sakarya vilâyeti teşkil edilmiştir. Bunun sonucu olarak da Kocaeli'nin hem nüfusu hem de öğrenci sayıları yarı yarıya düşmüş ve ilkokul sayısı 177'ye gerilemiştir. Bu okulların 19'u şehir merkezlerinde 158'i de köylerde yer almaktadır. Ayrıca il genelinde vazifeli 441 öğretmenin 215 şehirlerdeki ve 226’sı da köylerdeki okullarda çalışmaktadır. $^{28}$

Eğitim ve öğretimin kalitesini arttırmak amacıyla1955 yılı içerisinde İzmit'te Mehmetaliapaşa, Derince, Cedit ve Hacı Hasan Mahallelerinde birer ilkokul daha inşa edilmiştir. Mehmetaliapaşa'da mevcut 28 Haziran İlkokulu'nun yanında açılan okula Yenimahalle adı verilmiştir. Diğer iki yerde açılan ilkokullar da aynı şekilde yapıldıkları mahallelerin adıyla anılmışlardır. ${ }^{29}$ Bahsi geçen ilçede yeni ilkokulların açılmasının yanında var olan okulların bir kısmı da tamir edilmiştir. Bu okullardan birisi Yeni Turan İlkokuludur. ${ }^{30}$ Tamir edilen ve teknik yönden güçlendirilen okul, eğitim hizmetlerine sunulmuştur.

Milli Eğitim Bakanlığı tarafından 1955 yılı bütçesinden Kocaeli’nde köy okulların sayısını arttırmak amacıyla 200.000 Türk Lirası tahsis edilmiştir. İlk önceleri vilâyet için ayrılan para köylerin okul ihtiyaçlarını karşılamada yeterli olmamıştır, ancak yine de bahsi geçen bütçe ile köy okullarının birçok eksiği kapatılmıştır. ${ }^{31}$ Bizim Şehir Gazetesi’ne göre daha sonraki

\footnotetext{
Demokrat Kocaeli, 30 Eylül 1953, No: 468.

Bizim Şehir, 15 Ocak 1954, No:508.

Bizim Şehir, 19 Ağustos 1954, No: 686.

DİGM, Milli Ĕgitim İstatistikleri İlköğretim (1953-1960), s.224.

Bizim Şehir, 3 Ağustos 1955, No: 980; Azim, 8 Eylül 1955, No: 324.

Azim, 27 Ocak 1955, No: 138.

Azim, 17 Mart 1955, No: 179.
} 
dönemlerde Milli Eğitim Bakanlığı bütçesinden vilâyette okul yaptırmak için ayrılan paranın miktarı arttırılmıştır. Bu yolla köy okullarının daha modern bir hale getirildiği ve eğitimin daha da geliştirildiği düşünülebilir.

Yukarıda belirtildiği gibi, 1955 yılında İzmit dışında Gebze dâhil diğer kazalarda da yeni okullar yapılmıştır. Bu kapsamda Gebze'de bir ilkokul inşa edilmiş ve eğitim-öğretim hizmetlerine sunulmuştur. Aynı şekilde Hereke nahiyesinde de yeni bir ilkokulun temelleri atılmıştır. ${ }^{32} \mathrm{Bu}$ dönemlerde okulların güvenli bir hale getirilmesi ve öğrencilerin rahatça okula gitmelerini temin etmek amaciyla İzmit Belediye Bakanlığı tarafından birtakım önlemler alınmış ve okul önlerinde güvenliği sağlamak üzere trafik polisleri görevlendirilmiştir. Ayrıca İzmit Belediyesi tarafından de trafiğe açık olan okul önlerinde öğrencilerin giriş ve çıkış saatlerini sağlamak amac1yla birer memur görevlendirilmiştir. ${ }^{33}$

1954 yılında Sakarya Vilâyetinin teşekkülünden sonra Kocaeli'ndeki ilkokulların sayılarında yarı yarıya azalmıştır. Daha sonraki dönem olan 1956-1957 Eğitim-Öğretim Y1lında Kocaeli'ndeki ilkokul sayıları yeniden artış göstermiş ve 178'e yükselmiştir. Bu okullardan 21'i şehir merkezlerinde ve 157'si de köylerdedir. Ayrıca bu dönemde Kocaeli genelinde 445 öğretmen vardır ve bu öğretmenlerden 235'i köylerdeki ilkokullarda görev almıştır. Okul ve öğretmen sayılarındaki bu artışlar 1957-158 döneminde de devam etmiş ve ilkokulların sayısı 187 'ye çıkmış ve öğretmenlerin sayısı da 448 olmuştur. $^{34}$

Kocaeli'nde okul sayılarının arttığı bu dönemlerde başka gelişmeler de görülmektedir. Söz konusu gelişme, 1957 yılında Karayolları tarafindan İzmit'te bazı yerlerin istimlâk edilmesi üzerine Necatibey İlkokulu'nun y1kılmasına karar verilmesidir. Adı geçen okulun yıkılması üzerine bölgedeki okul ihtiyacını karşılamak amacıyla yeni bir yapının temelleri atılmıştır. Yenidoğan adıyla açılan ilkokul 196.000 Türk Lirası'na mal olmuş ve müessesenin bütün masrafları SEKA Kâğıt Fabrikaları tarafından karşılanmıştır. ${ }^{35}$ Aynı yıl içinde vilâyet genelinde kötü durumda olan ve eğitim-öğretim açısından sorun teşkil eden birç̧ok ilkokul tamir edilmiştir. Bu bağlamda, Kandıra'daki Taşoluk İlkokulu 23.153 Türk Lirası, Müezzinler Köyü İlkokulu 23.133 Türk Lirası, Doğancılar Köyü İlkokulu 15.045 ve Gölcük’teki Öcün Köyü İlkokulu 16.602 Türk Lirası ile tamir edilmiştir. Bunun dışında diğer kazalarda yer alan Ciyaklar, Selametli ve Hasanpaşa Çiftlik İlkokulu olmak üzere 20 ilkokul daha onarılmıştır. ${ }^{36}$

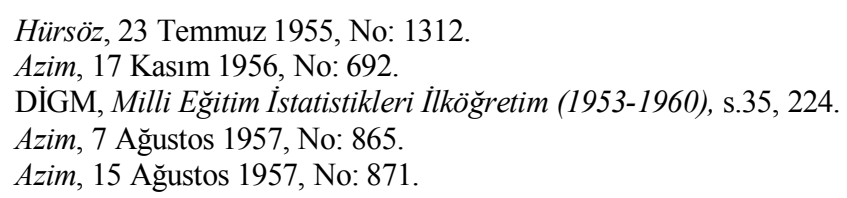


1957'de İzmit'te Yenimahalle adıyla yeni bir ilkokul daha inşa edilmiştir. 200.000 Türk Lirası'na mal olan okulun açılışına başta Kocaeli Valisi Ekmel Çetiner olmak üzere birçok kişi katılmıştır. Açılış töreninin ardından Yenimahalle İlkokulu 1957-1958 Eğitim-Öğretim yılı için eğitime başlamıştır. ${ }^{37}$ Aynı dönemlerde Gebze ve Derince'de yeni okulların yapılması için 296.547 Türk Lirası tahsis edilmiştir. Ayrıca Bağçeşme Mahallesi’nde iki katlı bir okul yapmak için de 296.542 Türk Lirası ayrılmıştır. ${ }^{38} 1958$ 'de Akmeşe'deki 3 katlı okul tamir edilmiş ve yatılı okul haline getirilmiştir. $\mathrm{Bu}$ iş için Milli Eğitim Bakanlığı'ndan 42.000 Türk Lirası tahsis edilmiştir. Ayrıca okulun diğer ihtiyaçlarını karşılamak amacıyla da Milli Eğitim Müdürlüğü tarafından 90.000 Türk Lirası harcanmıştır. Bu yatılı okulda her yıl 150 öğrenci barındırılmaktadır. ${ }^{39}$

1959 yılında Kocaeli'nde 7 adet daha ilkokul yapılmış ve ilkokulların sayısı 194'e çıkarılmıştır. Bu okullarda toplam 448 öğretmen görev yapmaktadır. Son olarak 1960'ta Kocaeli'nde 199 ilkokul ve bu okullarda 519 öğretmen bulunmaktadır. ${ }^{40}$ DP'nin son dönemi olan 1960 'ta Kocaeli'nde büyük bir eğitim seferberliği başlatılmıştır. Bu gelişmeler kapsamında sürdürülen ilkokul seferberliği olumlu sonuçlar vermiş ve vilâyet dâhilinde çok sayıda köye ilkokul yapılmıştır. Okul inşa edilemeyen yerlerde ise portatif okular kullanılmıştır. Demokrat Kocaeli Gazetesi'ne göre bu okullar, eğitim ve öğretim faaliyetlerini kolaylaştırmıştır. ${ }^{41}$

\section{Ortaokullar}

Kocaeli ve Kocaeli'nden ayrılan ilçelerin birleşmesiyle 1954'te vilâyet olan Sakarya' daki ortaokulların sayısı aşağıda tablolar halinde gösterilmiştir. Kocaeli hudutları dâhilinde DP devrinde çok sayıda ortaokul açıldığını göstermek amaciyla Sakarya vilâyeti teşekkül etmeden önce Kocaeli'nin kazaları olan Adapazarı, Hendek, Karasu, Akyazı ve Geyve'nin de ortaokul sayıları Kocaeli ile birlikte verilmiştir. ${ }^{42}$

Tablodan da açıkça görülebileceği üzere DP döneminde Kocaeli'nin bütün kazalarında ortaokul sayıları çoğalmıştır. 1950 yılında 12 olan ortaokul sayısı 1960 'ta 45'e yükselmiştir. Yani ortaokulların sayısı \% 315 gibi büyük bir artış olmuştur. Söz konusu durum, bu dönemde eğitim faaliyetlerine değer verildiği şeklinde değerlendirilmektedir.

Azim, 28 Haziran 1957, No: 826.

Azim, 20 Temmuz 1958, No: 1206.

Azim, 15 Kasim 1958, No: 713.

DİGM, Milli Eğitim İstatistikleri İlköğretim (1953-1960), s.35, 224.

Demokrat Kocaeli, 19 Mart 1960, No: 2378.

42 DİGM, Milli Eğitim İstatistikleri Ortaokul 1951, Ankara, s.66-106; DİGM, Milli Eğitim Istatistikleri Ortaokul (1953-1961), Ankara 1963, s. 123,124, 224. 
Tablo 3: Kocaeli'ndeki Ortaokulların Sayısı

(Adapazarı, Hendek, Geyve, Karasu ve Akyazı İlçeleri Kocaeli’nden Ayrılmadan Önce)

\begin{tabular}{|l|c|c|}
\hline \multirow{2}{*}{ İlçeler } & $\mathbf{1 9 5 0}$ & $\mathbf{1 9 6 0}$ \\
\cline { 2 - 3 } & $\begin{array}{c}\text { Kent merkezi ile } \\
\text { köylerdeki ortaokullar }\end{array}$ & $\begin{array}{c}\text { Kent merkezi ile } \\
\text { köylerdeki ortaokullar }\end{array}$ \\
\hline İzmit & 2 & 10 \\
\hline *Adapazar1 & 2 & 6 \\
\hline *Akyaz1 & 1 & 3 \\
\hline Gebze & 1 & 3 \\
\hline *Geyve & 1 & 2 \\
\hline Gölcük & 1 & 3 \\
\hline$*$ Hendek & 1 & 6 \\
\hline Kandira & 1 & 4 \\
\hline Karamürsel & 1 & 5 \\
\hline *Karasu & 1 & 3 \\
\hline Toplam & 12 & 45 \\
\hline
\end{tabular}

1954'te Sakarya vilâyetinin teşekkül etmesi ile Kocaeli'ndeki ortaokulların sayısı da ilkokul sayılarında olduğu gibi yarı yarıya azalmıştır. Aşağıdaki tabloda Sakarya'nın il olmasıyla beş ilçesi eksilen ve sadece 5 ilçesi kalan Kocaeli'nde mevcut ilçelerden İzmit, Karamürsel, Gebze, Kandıra ve Gölcük kazalarındaki ortaokul sayıları gösterilmiştir: ${ }^{44}$

Tablo 4: 1950 ile 1960 Yılları Arasında Kocaeli'ndeki Orta Okulların Sayıları (Sakarya vilâyeti kurulduktan sonra)

\begin{tabular}{|l|c|c|}
\hline Ortaokullar & \multicolumn{1}{|c|}{$\mathbf{1 9 5 0}$} & $\mathbf{1 9 6 0}$ \\
\hline İlçeler & $\begin{array}{l}\text { Kent merkezi ile } \\
\text { köylerdeki ortaokullar }\end{array}$ & $\begin{array}{c}\text { Kent merkezi ile } \\
\text { köylerdeki ortaokullar }\end{array}$ \\
\hline İzmit & 2 & 10 \\
\hline Gebze & 1 & 3 \\
\hline Gölcük & 1 & 3 \\
\hline Kandıra & 1 & 4 \\
\hline Karamürsel & 1 & 5 \\
\hline Toplam & 6 & 25 \\
\hline
\end{tabular}

43 **Bu işaretler, Kocaeli'nden ayrılan ve Sakarya vilâyetine bağlanan ilçeleri ifade etmektedir.

44 DİGM, Milli Eğitim İstatistikleri Ortaokul (1950-1951), s.66-106; DİGM, Milli Eğitim İstatistikleri Ortaokul (1953-1961), s. 123,124, 224. 
Tablodan da anlaşılacağı üzere, beş kazanın Kocaeli'nden ayrılması ile ortaokul sayılarında büyük azalmalar olmuştur. Bu kapsamda 1960 yılında Kocaeli'ndeki ortaokulların sayısı 25'tir.1950 ile 1960 arasındaki dönemde Kocaeli'nde eğitimi kalitesini yükseltmek amaciyla ilkokullar kadar olmasa da ortaokulların da yapımına ağılık verilmiş ve sayıları arttırılmıştır. Bu devrede Kocaeli'nde ilçe merkezleri dışında bucak ve köylerde de ortaokullar yapılmıştır. Bilhassa vilâyette ortaokulların sayısının artmasına bağlı ortaokul öğrencilerinin sayıları da yükselmiştir. ${ }^{45}$ Burada üzerinde durulan veriler DP'nin iktidara geldiği 1950 ile DP'nin son dönemi olan 1960 yılını kapsamaktadır. Ara dönemdeki yılların verileri ise şu şekildedir:

1950-1951 Eğitim-Öğretim Dönemi'nde Kocaeli’nde 7 ortaokul bulunmaktadır. Buna göre İzmit, Adapazarı, Gebze, Gölcük, Karamürsel ve Hendek ilçelerinde birer ortaokul bulunmaktadır. ${ }^{46} \mathrm{Bu}$ yıllarda Kocaeli genelindeki 7 ortaokulda 74 öğretmen görev yapmakta olup toplam öğrenci sayısı 1.195'tir. Bu dönemdeki ortaokul öğrencilerinden 135 erkek ve 45 kadın olmak üzere 180 kişi diploma almıştır. ${ }^{47}$ Aynı dönem içerisinde Kocaeli'ndeki resmi liselere bağlı ortaokullardan 61'i kadın ve 22'si erkek olmak üzere 83 kişi diploma almaya hak kazanmıştır. ${ }^{48} 1951$ yılında Kocaeli ortaokulları müfredatlarında yer yabancı diller İngilizce, Fransızca ve Almancadir. ${ }^{49}$

1953-1960 seneleri arasında Kocaeli’ndeki ortaokullardaki öğrenci sayıları şu şekildedir: 1953 yılında 1.301, 1954 yılında 509, 1955 yılında 690, 1956 yilında 893, 1957 y1linda 1.049, 1958 yilında 745 ve 1959 yılında 843 kişi ortaokulda eğitim almıştır. 1953-1960 yılları arasında en fazla ortaokul öğrencisi 1.301 ile 1951 ve en az öğrenci sayısı ise 509 ile 1954 yılıdır. $\mathrm{Bu}$ yıllarda kadın öğrencilerin sayıca en fazla olduğu yıl da 317 ile 1951 y1lidir. ${ }^{50}$

1950 ile 1960 arasındaki dönemde Kocaeli’nde eğitimi kalitesini yükseltmek amaciyla ilkokullar kadar olmasa da ortaokulların da yapımına ağırlık verilmiş ve sayıları arttırılmıştır. Bu devrede Kocaeli'nde ilçe merkezleri dışında bucak ve köylerde de ortaokullar yapılmıştır. Bilhassa vilâyette ortaokulların sayısının artmasına bağlı ortaokul öğrencilerinin sayıları da yükselmiştir. ${ }^{51}$

\footnotetext{
"Kocaeli”, Yurt Ansiklopedisi, s.5056.

DİGM, Milli Eğitim İstatistikleri Ortaokul (1950-1951), s.7.

DİGM, 1952 Ístatistik Ylllı̆̆l, Ankara 1953, s.162.

DİGM, Milli Eğitim İstatistikleri Ortaokul (1950-1951), Ankara 1952, s.159.

49 DİGM, Milli Eğitim İstatistikleri Ortaokul (1950-1951), s. 195.

50 DİGM, Milli Eğitim İstatistikleri Ortaokul (1953-1960), Ankara 1960, s.159.

51 "Kocaeli", Yurt Ansiklopedisi, s.5056.
} 
1951'de Milli Eğitim Bakanlığı'nın aldığı karar ile Adapazarı Erkek Sanat Okulu, Erkek Sanat Enstitüsü'ne dönüştürülmüş ${ }^{52}$ ve aynı yıl içinde Geyve'de bir ortaokul yaptırılmıştır. ${ }^{53}$ Aynı şekilde 1952 yılı içerisinde Kandıra'da ilçenin adıyla yeni bir ortaokulu açılmıştır. ${ }^{54} 1953$ 'te ise Gölcük'te bir ortaokul yaptırılmış ve 1 Eylül 1953'te eğitim ve öğretim yılına hazır duruma getirilen okulun açılış törenine Vali Ethem Yetkiner, Donanma Komutanı Koramiral Kemalettin Bozkurt, Tümamiral Fahri Korutürk, Gölcük Kaymakamı Sabri Berkan, Gölcük ve Değirmendere belediyeleri ile yüksek rütbeli subay ve büyük bir kalabalık katılmıştır ${ }^{55}$.Adı geçen mektep yapılmadan önce ilçede eğitim faaliyetleri çift tedrisatlı şeklinde yürütülmektedir ve bu da öğrenciler için sıkıntılar oluşturmaktadır. Bu anlamda Gölcük Ortaokulu'nun açılması ile kazada eğitim faaliyetlerinin daha rahat yürütülmeye başlandı̆̆ düşünülebilir. ${ }^{56}$

1954'te Akyazı kazası ile Hereke nahiyesinde birer adet ortaokul inşa edilmesi için gerekli altyapı çalışmaları yapılmış ve aynı yıl içinde yapımı tamamlanan Akyazı Ortaokulu ile 1955'te bitirilen Hereke Ortaokulu eğitim ve öğretime hazır vaziyete getirilmiştir. ${ }^{57}$ Söz konusu okulun açılışı ile ilgili İstiklal Gazetesi tarafından şu bilgiler verilmiştir: ${ }^{58}$

"Yapımına daha evvel başlanan Hereke Ortaokulu, Hereke Okul Yaptırma Derneği tarafindan yaptırılmıştır. Bu okulda 26 Eylül Salı gününden itibaren tedrisat başlamıştır. Gayet güzel yapılan binaya ve kayıt olan 101 talebeye rağmen; okulda halen iki öğretmen vardır. Bu durum öğrenci velileri tarafindan üzüntü ile karşılanmaktadır. Ortaokulun birinci sınıfında 58 ve ikinci sınıfında ise 43 öğrenci vardır. Öğretmen yokluğundan birinci sınıf öğrencileri tek sınıfta okutulmaktadır. Kocaeli'nin birçok ortaokulunda 20 ile 40 öğrenciye 5 ya da 6 öğretmen düşerken; 101 talebelik okula sadece iki öğretmen az görülmektedir. İlgili Maarif Vekâlet'inin ehemmiyetle dikkatini çekeriz."

İzmit'te ortaokul öğrencilerin yatılı olarak okuyabilecekleri yatılı bir ortaokul yaptırılması için Valilik tarafından çalışmalar yürütülmüştür. Bu dönemlerde İzmit'te eski hastane binalarında orta dereceli okullara devam eden talebeleri barındıran bir yurt bulunmaktadır. Yurdun ihtiyaçları Özel İdare Müdürlüğü ile İzmit Belediyesi tarafindan karşılanmaktaydı ve yurtta 38 öğrenci barınmaktadır. Bu yurdun daha kapsamlı bir hale getirilmesi için

\footnotetext{
52 Enis Şahin, Kronolojik Adapazarı Sakarya 1923-2004, Sakarya 2004. s.74.

53 ATOM, Sinop, Sakarya, İzmit, Edirne, Tekirdăg, s.159.

54 Hürsöz, 22 Ekim 1952, No: 471.

55 Demokrat Kocaeli, 1 Eylül 1953, No: 469.

56 Türk Yolu, 26 Eylül 1953, No: 4594.

57 İstiklal, 16 Kasım 1954, No: 44; İstiklal, 27 Eylül 1955, No: 307.

58 Istiklal, 27 Eylül 1955, No: 307.
} 
Kocaeli Orta Dereceli Okular Fakir Öğrencileri Barındırma ve Bakım Derneği adıyla bir dernek kurulmuştur. ${ }^{59}$ Bahsi geçen derneğin faaliyetleri sonucunda İzmit'te bir yurt yaptırılmış ve bu yurttan çok sayıda öğrenci faydalanmışır.

1956'da hem nüfus artışı hem de göçler nedeniyle İzmit'teki ortaokullar yetersiz gelmeye başlamış ve bu durumdan dolayı yeni bir ortaokulun açılması elzem bir durum arz etmiştir. Bu amaçla 60.000 Türk Lirası bedelle yeni bir mektebin temelleri atılmıştır. ${ }^{60} 1957$ 'de inşaatına başlanan okul 1958 yılı eğitim ve öğretim yılı başlamadan bitirilmiştir. 1959 yılı içerisinde de Kocaeli'nde okulların yapımına aralıksız devam edilmiş ve bu kapsamda Necatibey Ortaokulu'na bir şube daha eklenmiştir. Bu şubenin açılması ile İzmit merkezdeki ortaokulların kalabalık sınıflarının sayıları azalmış ve eğitim daha rahat bir şekilde yapılmaya başlanmıştır. ${ }^{61}$ Ayrıca Yenidoğan, Kozluk ve SEKA semtinde ikamet edenler bu ortaokulun ilk öğrencileri olmuşlardır. ${ }^{62} 1960$ yılı itibarıyla İzmit’te yer alan ortaokullar şunlardır: İzmit Merkez Ortaokulu, İnkılâp Ortaokulu, Akşam Ortaokulu, Derince Ortaokulu, Mimar Sinan Ortaokulu, Bahçecik Ortaokulu, Suadiye Ortaokulu, Derbent Ortaokulu, Akmeşe Ortaokulu, İmam Ortaokulu ve Necatibey Ortaokulu'dur. ${ }^{63}$

\section{Liseler}

1950-1951 Eğitim Öğretim Y1lında Kocaeli’nde düz lise seviyesinde sadece İzmit Lisesi adında bir eğitim kurumu bulunmaktadır. 17 Kasım 1945 'te devrin Milli Eğitim Müdürü olan Hasan Ali Yücel tarafından açılan bu lise, kentin en önemli eğitim kurumları arasında yer almaktadır. ${ }^{64} 1951$ 'de 8'i erkek 10'u kadın toplam 18 öğretmenin görev yaptığ bu lisede 191'i erkek ve 46' kadın olmak üzere 237 öğrenci eğitim görmektedir. Adı geçen dönemde 56's1 erkek ve 8 kadın olmak üzere 64 öğrenci mezun olarak diploma almaya hak kazanmıştır. ${ }^{65} \mathrm{Bu}$ yıllarda İzmit Liselerinde okutulan yabacı diller arasında en çok İngilizce tercih edilmektedir. İngilizceyi sırasiyla Fransizca ve Almanca takip etmektedir. ${ }^{66}$

\footnotetext{
59 Azim, 11 Nisan 1957, No: 816.

60 Azim, 18 Haziran 1957, No: 869.

61 Hürsöz, 15 Ekim 1959, No: 2975.

62 Bizim Sehir, 8 Ekim 1959.

63 Kocaeli 1967 İl Yillığı, Doğan Kardeş Matbaacılık, İzmit 1970. s. 122.

${ }^{64}$ Oya Şenyurt, "Bir Eğitimin İnşa Öyküsü ve Geçmişin Modern Mimarisi: "Lise Pavyonu"/ İzmit Lisesi, Uluslararası Gazi Süleyman Paşa ve Kocaeli Tarihi Sempozyumu, C: III, Kocaeli 2017, s.2197.

65 DİGM, 1952 Istatistik Ylllı̆ $\breve{l}$, s.163.

66 DİGM, Ortaögretim Istatistikleri (1951-1952), Ankara 1952, s.332.
} 
1951-1952 Eğitim Öğretim yılında 9'ü erkek 8'i kadın toplam 17 öğretmenin görev yaptığı bu İzmit Lisesi'nde 207'si erkek ve 56'sı kadın olmak üzere 263 öğrenci eğitim bulunmaktadır. Ayrıca söz konusu dönemde 1'i kadın ve 9'u erkek olmak üzere toplamda 10 öğrenci mezun olarak diploma almaya hak kazanmıştır. ${ }^{67}$ Görüldüğü gibi diploma alanlar arasında sadece 1 kadın öğrenci bulunmaktadır. Bu da dönem itibarıyla kadınların eğitim-öğretim içerisinde ne derece küçük oranlarda okula gidebildiklerini göstermesi açısından çarpıcıdır.

1952-1953 ders yılında toplam 9 şubesi bulunan İzmit Lisesi'nin 284'ü erkek ve 77'si kadın olmak üzere toplamda 361 öğrencisi mevcuttur. ${ }^{68}$ Ayrıca bu dönemde mezun olarak diploma alabilen kişi sayısı 70'dir. 19531954 döneminde 446's1 erkek 201'i kadın olmak üzere 647 öğrenci vardır ve 112'si erkek 36'sı kadın 148 kişi lise diploması almıştır. 1954-1955 devrinde aynı şekilde 506'sı erkek 246'sı kadın toplamda 752 öğrenci vardır ve bu dönemde her iki liseden 76'sı erkek 44'ü kadın olmak üzere 110 öğrenci diploma almaya hak kazanmıştır. ${ }^{69}$

1955-1956 yılı eğitim-öğretim döneminde 559'u erkek ve 252'si kadın olmak üzere 811 lise öğrencisi vardır ve bunlar arasında 75'i erkek 22'si kadın toplamda 97 kişi mezun olarak lise diplomalarını almışlardır. Bunun gibi 1956-1957 Eğitim-Öğretim Dönemi'nde 657'si erkek ve 300'ü kadın öğrenci olmak üzere 957 lise talebesi mevcuttur ve bunlar içerisinden 72 erkek ve 44 kadın öğrenci olmak üzere toplamda 116 lise öğrencisi mezun olarak diploma sahibi olmuşlardır. 1957-1958 döneminde Kocaeli genelinde lise öğrencisi sayılarında çok ciddi bir artış bulunmaktadır. Buna göre adı geçen devrede 752 erkek ve 345 kadın öğrenci öğrenciyle toplam 1.097 lise öğrencisi vardır ve bunlardan 99'u erkek ve 67'si kadın olmak üzere toplamda 166 kişi mezun olmuştur. ${ }^{70}$

1958 yılına kadar Kocaeli'nde İzmit dışındaki diğer ilçelerde lise bulunmadığı için öğrenciler İzmit'e gelmektedirler ve bu konuda birtakım zorluklar yaşamaktadırlar. Bu sıkıntılara örnek Gölcük ve Değirmendere'den İzmit'e Lisesi'ne gelen öğrencilerin yaşadıkları ve tanık oldukları Üsküdar Faciası olayı verilebilir. ${ }^{71} \mathrm{Bu}$ olaydan sonra Gölcük’te bir lise yapılmıştır. ${ }^{72}$

67 DİGM, 1953 İstatistik Yıllı̆̆ , Ankara 1964, s. 143.

68 DİGM, Ortaögretim Istatistikleri (1952-1953), Ankara 1957, s.338.

69 DİGM, Ortaögretim Istatistikleri (1953-1960), Ankara 1963, s.222.

70 DİGM, Ortaögretim İstatistikleri (1953-1960), s.222.

71 "Üsküdar Faciasl, Üsküdar vapuru faciası ya da Körfez Faciası olarak bilinen Türkiye Cumhuriyeti tarihinin en ölümcül sivil deniz kazasıdır. 1 Mart 1958'de İzmit - Gölcük arasında sefer yapan Üsküdar isimli vapur, İzmit iskelesinden hareket ettikten sonra Derince yakınlarında şiddetli rüzgâr sebebiyle batmışıı. Kayıplar hakkında net bir bilgi yoktur kimi kaynaklara göre 200-300 kimilerine göre 400-500 yolcu hayatını kaybetmiştir. Yolcuların çoğunu İzmit Lisesi ve İzmit Sanat Okulu talebeleri oluşturuyordu. Yolcularından yalnızca 40 kişi kadarı kurtulabilmiş, diğerleri dalgaların arasında kaybolup gitmiş̧ir. 1950'li 
$\mathrm{Bu}$ anlamda Gölcük Lisesi'nin faaliyete geçmesi ile Gölcük, Karamürsel, Ulaşlı ve Değirmendere'deki öğrencilerin daha rahat bir şekilde eğitim almaya başladıkları düşünülebilir.

1958'de Kocaeli'nde yeni bir lisenin açılmasıyla birlikte öğrenci sayıları artmıştır. Bu bağlamda 1958-1959 Eğitim-Öğretim yılında lise öğrenci sayısı bir önceki yıla göre $\% 75$ oranında büyümüş ve öğrenci sayıs1 1.097 'den 1.820'ye çıkmıştır. Bilhassa kadın öğrencilerin sayısı ciddi bir artış içerisinde olmuştur. Bunun gibi 1959-1960 döneminde de lise öğrencilerinin sayısı artmaya devam etmiş ve 1.466'sı erkek ve 633'ü kadın olmak üzere 2.099 öğrenci vardır ve bu öğrencilerden 196's1 erkek ve 81'i kadın 257 kişi lise diploması almaya hak kazanmıştır. ${ }^{73}$

Kocaeli'nde bu iki lise dışında meslek okulları da bulunmaktadır.19501951 Eğitim-Öğretim Dönemi'nde Kocaeli’nde sekiz tane orta dereceli meslek okulu bulunmaktadır. Adı geçen dönemde $165^{\prime}$ i kadın ve $1.388^{\prime} \mathrm{i}$ erkek toplamda 1.553 öğrencinin eğitim aldığı Kocaeli Meslek okullarından toplamda 106 öğrenci mezun olmuştur. ${ }^{74} 1952-1953$ döneminde ise Kocaeli’nde meslek okullarına 163 kişi daha kayıt yaptırmışıır. ${ }^{75}$ 1953-1960 arasındaki dönemde meslek okullarına 1.000 kişi kayıt olmuş ve bunların da \% 60’1 mezun olmaya hak kazanmıştır.

1950-1951'de Kocaeli Adapazarı Orta Ticaret Okuluna 16's1 erkek ve 3’ü kadın olmak üzere 19 kişi kayıt olmuştur. ${ }^{76}$ Adapazarı Orta Ticaret Okulu'nun öğrenci sayısı ise dönem başında 67 kişidir. ${ }^{77}$ Daha sonraki dönemlerde 16 öğrenci okuldan ayrılmış ve sadece 24 öğrenci mezun olabilmiştir. ${ }^{78} 1952-1953$ devrinde okulda 2'si kadın 6's1 erkek toplamda 8

yıllarda Karamürsel ve Gölcük'te lise yoktu. Kara ulaşım vasitaları da kisitllydı. Bu sahil ilçelerinin gençleri ayn zamanda ekonomik olan vapur yolculuğunu tercih ediyorlard. Cumartesi günleri yarım gün eğitim verildiğinden, öğle tatiliyle birlikte öğrencilerin tamamına yakını vapura bindi. Derince açılarına gelindiğinde şiddetli firtınaya yakalanan ve çoğu kısmı ahşap olan Üsküdar vapurunun kaptan köşkü uçtu. Kumandasız kalan vapur, yan yatarak battı. Bazı kayıtlarda vapurun ikiye bölündügüünden de söz edilir. Gölcük'teki Donanma Komutanlı̆̆ı'na ait Deniz Üssü'nden yardıma gelen denizaltı ve savaş gemileri, denize dökülen yolcuların ancak küçük bir bölümünü kurtarabildi. Gölcük Barbaros Hayrettin Lisesi bu olayın ardından kurulmuştur"

https://tr.wikipedia.org/wiki/1_Mart_1958_\%C4\%B0zmit_deniz_kazas\%C4\%B1

(15.10.2013).

72 Yavuz İzmit, 16 Ocak 1960, No: 3122.

73 DİGM, Ortaögretim İstatistikleri (1953-1960), s.222.

74 DïGM, 1952 İstatistik Yillığı, s. 166.

75 DİGM, Meslek, Teknik ve Yüksekögretim (1952-53), Ankara 1954, s. 6.

76 DIGM, Meslek, Teknik ve Yüksekögretim (1950-51), Ankara 1952, s. 5.

77 DİGM, Meslek, Teknik ve Yüksekögretim (1950-51), s. 5.

78 DİGM, Meslek, Teknik ve Yüksekögretim (1952-53), s. 137-138. 
öğretmen vazife okula 31'i erkek ve 6's1 kadın olmak üzere 37 yeni öğrenci kayit yaptırmıştır. $^{79}$

1930'larda İzmit'te bir adet İzmit Kız Enstitüsü bulunmaktadır. Bu enstitü dışında yapımına 1945'lerde başlanan ve 1952 eğitim öğretim yılında hazır hale getirilen Erkek Enstitüsü de vardı. Kız ve Erkek Enstitüleri 1950 'den itibaren sürekli olarak teknik ve personel yönden güçlendirilmişlerdir. Bu kapsamda 1956 yılında İzmit Erkek Enstitüsü’nün okul idare birliği yeni idare kurulunun ilk toplantısı yapılmıştır. Bu toplantıya veliler ve idareciler katılmış ve önemli kararlar alınmıştır. Okulun tamamlanamayan yerlerinin bulunduğu belirtilmiş, marangoz ile makine atölyelerinin tamamlanması ve motorculuk şubesinin açılması gerektiği vurgulanmıştır. Enstitünün adı geçen eksiklikleri Vali Ekmel Çetiner tarafından dikkate alınmış ve okulun noksan inşaatının ikmali için çalışılarak, programa dâhil edilmiştir. Bu dönemde atölyelerin, yemekhane, müzakere salonları ve güneş gören, hava alan kısımların ilavesi için 355.500 Türk Lirası ile ihale kararı alınmıştır. ${ }^{80} 1949$ yılında açılan İzmit Erkek Sanat Enstitüsü'nün mevcut bölümlerine marangozluk da eklenmiş, okul binasının alan olarak genişlemesi ve yeni bölümlere kavuşması temin edilmiştir. $\mathrm{Bu}$ durum vilâyet genelinde memnuniyet ile karşılanmıştır. ${ }^{81}$ Daha sonraları Erkek Sanat Enstitüsü'nde bölümlerde eğitim alan öğrencilere kendi yerleri yetersiz geldiğinden dolayı, ilave edilen bölümler, öğrencilere tahsis edilmiştir. Böylece okulun birçok eksiliği giderilmiştir. ${ }^{82}$

1950-1951 Eğitim-Öğretim Dönemi'nde İzmit Kız Sanat Enstitüsü’ne 40 öğrenci kayıt yaptırmıştır. ${ }^{83}$ Beş sınıfın, yedi şubeye bölündüğü enstitünün bu ders döneminde sene başında 145, yılsonunda ise 21 öğrenci mevcudu vardır. ${ }^{84}$ Ayrıca İzmit Kız Sanat Enstitüsü'ne 1952-1953 yılları arasında 28 ve 1953-1960 arasında ise 592 öğrenci kayıt yaptırmıştır. ${ }^{85}$ Enstitüden 1952-53 döneminde 29 öğrenci mezun olmuş ve üç öğrenci de ayrılmıştır. ${ }^{86} 22$ Kadın öğretmenin görev yaptığı enstitüden ${ }^{87}$ çeşitli sebep-

\footnotetext{
79 DİGM, Meslek, Teknik ve Yükseköğretim (1952-53), s. 7-244.

80 Tunç, Demokrat Parti Dönemi'nde Kocaeli, s.468.

81 Oya Şenyurt, 1923-1960 Yılları Arasında İzmit'te İnşa Edilen Yapılar ve Kentin Gelişimine Katkıları, Uluslararası Gazi Akça Koca ve Kocaeli Tarihi Sempozyumu, C: I, Kocaeli 2015, s.1673.

82 Fügen Avdan, Cumhuriyet Döneminde Kentleşme Sürecinde Planlama Deneyimi, 19301980 İzmit Planları, Kocaeli Üniversitesi Sosyal Bilimler Enstitüsü, Basılmamış Yüksek Lisans Tezi, Kocaeli 2009, s. 78.

83 DIGG, Meslek, Teknik ve Yükseköğretim (1950-51), s. 4.

84 DİGM, Meslek, Teknik ve Yükseköğretim (1950-51), s. 4-40.

85 DİGM, Meslek, Teknik ve Yükseköğretim (1952-53), s. 4; DİGM, Meslek, Teknik ve Yüksekögretim (1953-60), Ankara 1963, s.155-159.

86 DiGM, Meslek, Teknik ve Yüksekögrretim (1952-53), s. 154-162.

87 DİGM, Meslek, Teknik ve Yüksekögretim (1952-53), s. 239.
} 
lerle 102 öğrenci ayrılmıştır. ${ }^{88}$ Kız Enstitüsü okulundaki öğrenciler biçki dikiş, elbise, çiçek, resim ve nakış eğitimi almışlardır. ${ }^{89}$

İzmit Kız Sanat Enstitüsü tarafından y1lın belirli günlerinde çeşitli defileler de düzenlenmektedir. Özelikle bu defilelerde kullanılan elbiseler İzmit Kız Sanat Enstitüsü öğrencileri tarafından podyumda sergilenmektedir. Yukarıda ifade edildiği gibi, bu tür faaliyetlere vatandaşlar tarafindan büyük ilgi gösterilmektedir. Özellikle Orduevinde düzenlenen y1lsonu defilelerine yoğun katılımlar olmaktadır. İzmit Kız Sanat Enstitüsü öğrencileri tarafından yapılan ve genellikle yerli kumaşlardan dikilen giysiler, o dönemlerde İzmit modasını belirlemektedir. Modern çağın gereklerine göre dikilen giysiler, vatandaşlar tarafından ilgi ile karşılanmaktadır. Kısacası bu enstitülerde düzenlenen sergiler ve defileler, 1950'lilerde Kocaeli'nin önemli kültürel faaliyetleri arasındadır. ${ }^{90}$

Kocaeli'nde dönem itibarıyla ilkokulların dördüncü ve beşinci sınıflarında okuyan öğrencilerin oluşturduğu ve her biri birer şube olmak üzere iki şube şeklinde örgütlenmiş olan Erkek Sanat Enstitüsü'nün eğitimöğretim yılının mezun başlangıcında 57, sonunda ise 50 öğrencisi bulunmaktadır. Vilâyetteki 2 adet erkek sanat enstitülerinden 1951 yılında 2 kişi devamsızlık ve 5 kişi de tasdikname almak gibi sebeplerden okuldan ayrılmış ve bu okuldan 43 kişi mezun olmuştur. ${ }^{91}$

1952-1953 Eğitim-Öğretim Dönemi’nde 64 öğrencisi olan Erkek Sanat Enstitüsü'nden 54 kişi mezun olmuştur. ${ }^{92}$ Dönem içinde enstitünün hem öğrenci sayısı hem de mezunları sürekli olarak artmıştır. Bu enstitüye bağlı 3 Kasım 1958'de açılan bir adet Akşam Tekniker Okulu bulunmaktadır. Erkek Sanat Enstitüsü içinde eğitim vermeye başlayan Akşam Tekniker Okulu, makine, elektrik ve kâğıt bölümlerinde teknisyen yetiştirmek amacıyla faaliyet yürütmektedir. Bu okulda eğitim üç yıldır ve eğitimler 18.00 ile 22.00 saatleri arasında yapılmaktadır.1958'de Hereke'den 3 sanat okulu mezunu imtihanları kazanarak Akşam Tekniker Okulu'na girmeyi hak kazanmıştır. 1959 yılında ise Akşam Tekniker Okulunda toplamda 220 ögrenci ders görmektedir. ${ }^{93}$

Türkiye genelinde birçok Köy Enstitüsünün açıldığı tarihlerde Kocaeli'ndeki Arifiye Köy Enstitüsü de 17 Nisan 1940 tarihinde 3803 sayılı kanunla kurulmuş ve kurucu müdür olarak Süleyman Edip Balkır atanmıştır. Köy Enstitüleri Kanunu gereği Arifiye Köy Enstitüsü bölgesine giren iller

\footnotetext{
DİGM, Ortaöğretim İstatistikleri (1953-1960), s.510.

DİGM, Meslek, Teknik ve Yüksekögretim (1952-53), s. 302.

Tunç, Demokrat Parti Dönemi'nde Kocaeli, s.469.

DİGM, Meslek, Teknik ve Yükseköğretim (1950-51), s. 52-142.

DíGM, Meslek, Teknik ve Yükseköğretim (1952-53), s. 129.

Istiklal, 4 Kasim 1958, No: 1230.
} 
Bursa, Bilecik ve İstanbul olarak belirlenmesine rağmen; buraya sadece Kocaeli, Bursa, Bolu, İstanbul ve Bilecik’ten öğrenciler alınmıştır. Açıldığı y1l itibariyle öğretim kadrosu hemen hemen yok sayılabilecek Arifiye Köy Enstitüsü'nde Edip Balkır tarafından kadro tamamlama çalışmaları başlatılmış ve 1940 yılından 1943 yılına kadar bu enstitüye 41 öğretmen atanmıştır.

Kuruluş yıllarında Arifiye Köy Enstitüsü'nde ziraat dersleri kapsamında okutulan ve uygulamalı olan derslerden biri de "Balıkçılık ve Su Mahsulleri" dersidir. Kocaeli yöresinin su kaynakları açısından zengin olmas1 nedeniyle, Arifiye Köy Enstitüsü'nde bu dersin uygulaması hem Sapanca Gölü’nde hem de İzmit Körfezi'nde yapılmıştır. Arifiye Köy Enstitüsü gerek Sapanca Gölü, gerekse İzmir Körfezi'ndeki balıkçlık çalışmalarının enstitü yaşamına birçok katkı sağlamıştır. Bunlardan ilki, enstitü öğrencilerinin bu sayede yüzme öğrenmesidir. Diğeri, balıkçılık çalışmaları kapsamında öğrencilere kayık kullanma, kürek çekme, balık avlama ve tuzlama gibi birçok teknik konunun öğretilmesiyle öğrencilerin balıkçılık konusundaki yeteneklerinin geliştirilmesidir. Böylelikle tıpk1 diğer enstitülerde olduğu gibi Arifiye Köy Enstitüsü'nde de iş içinde eğitim ilkesiyle enstitü yaşamı zenginleştirilmiştir. ${ }^{94}$

Arifiye Köy Enstitüsü’ne 1951-1952 Eğitim-Öğretim Dönemi'nde tümü erkek olmak üzere 49 yeni öğrenci kayıt yaptırmıştır. Bu dönemde adı geçen enstitüde 5 sinıf, 12 şubeye bölünmüş olup enstitü öğrenci sayıs1 749 'dur. ${ }^{95} 1950$ yılında okuldan biri ölüm, biri hastalık, biri devamsızlı,, altısı tasdikname, ikisi sınıfta kalma ve üçü de okuldan kovulma gibi nedenlerle toplam 16 ögrenci okuldan ayrılmıştır. Ayrıca bu yılda Arifiye Köy Enstitüsü'nden 108 kişi mezun olmuştur. ${ }^{96}$ Bir diğer dönem olan 1952 yılında okula 49 yeni öğrencini kayıt başvurusunda bulunduğu okulda 21 erkek ve 7'si kadın olmak üzere 28 öğretmen görev yapmaktadır. ${ }^{97} 1954$ 'te Sakarya vilâyetinin teşekkülü ile Arifiye Köy Enstitüsü bu vilâyete bağlanmıştır. ${ }^{98}$ Netice itibarıla 1960'lı y1llarda Kocaeli'nde 2 adet normal lise, 2 adet ticaret lisesi, 1adet erkek sanat enstitüsü ve 4 adet kız enstitüsü bulunmaktadır. Bu dönemlerde lisede okuyan öğrencilerin sayıları da sürekli şekilde artı̧̧ göstermektedir. Kocaeli dâhilinde 1950'de 300 olan lise öğrencisi sayıs1 1955 'te 442 ve 1960 'ta 642 olmuştur. ${ }^{99}$

94 Gülşah Eser, “Arifiye Köy Enstitüsü’nün Sapanca Gölü ve İzmit Körfezi’ndeki Balıkçılık Çalışmaları", Uluslararası Gazi Akça Koca ve Kocaeli Tarihi Sempozyumu, C: I, Kocaeli 2015, s. 1235-1241.

95 DİGM, Meslek, Teknik ve Yüksekögrretim (1950-51), s. 3-13.

96 DİGM, Meslek, Teknik ve Yüksekögrretim (1950-51), s. 126-137.

97 DIGM, Meslek, Teknik ve Yüksekögrretim (1952-53), s. 4-236.

98 DİGM, Ortaöğretim İstatistikleri (1953-1960), s.25-26.

$99 \quad 1967$ Kocaeli Il Yillı̆̆l, s. 122. 


\section{Imam Hatip Okullart}

DP'nin din eğitimi konusundaki görüşleri doğrultusunda 1951'de İmam Hatip Okulları açılmıştır. 1956 yılında ise, ortaöğretimin tamamına seçmeli din dersi konulmuştur. ${ }^{100} \mathrm{Bu}$ bağlamda, Kocaeli'nde bu okulların inşası için gerekli altyapı çalışmaları yapılmış ve İl Genel Meclisi'nde istişareler neticesinde vilâyet dâhilinde imam hatip ortaokullarının inşa edilmesine karar verilmiştir. ${ }^{101}$ Bunun için Kocaeli İmam Hatip Okulları Yaptırma Derneği kurulmuş ve fahri başkanlığına da Vali Cemal Babaç'ın seçildiği derneğin müteşebbis heyetinde kentin ileri gelenlerinden Dr. Ziya Gökşin, Mustafa Özbey, Adil Girgin, Tayyar Kobak, Rauf Özmen ve Yavuz Atan yer almışlardır. ${ }^{102}$ Müteakiben kazalarda da bu derneğin kurulması için Vali tarafından gerekli düzenlemeler icra edilmiş ve Gebze, Bahçecik, Hereke'de ayrı müteşebbis heyetler kurulmuştur. ${ }^{103}$ İzmit'ten sonra Gölcük'te de söz konusu dernek kurulmuş ve bunun sonucunda Kaymakam Faruk Cemal Vekfioğlu başkanlığında kurulan Gölcük İmam Hatip Ortaokulu Yaptırma Derneği'nin müteşebbis heyetinde şu kişiler yer almaktadır: Gölcük Belediye Başkanı İbrahim Şentürk, Maarif Memuru Bedri Soyalp, Değirmendere Belediye Başkanı Hüseyin Yücer, İl Genel Meclisi Üyesi Osman Uzuner ile Tüccar Fikri Öz. ${ }^{104}$

İzmit İmam Hatip Okulu Yaptırma Derneği'nin çalışmaları sonucunda 1955 'te kazada bir imam hatip ortaokulu açılması için hazırlıklara başlanmış ve okulun inşası için İzmit Belediyesi tarafından yer temin edilmiştir. ${ }^{105}$ Okulun yapımına katkı için Valilik tarafından Emlak ve Kredi Bankası'nda bir hesap açtırılarak bağış kampanyası başlatılmış ve teberru zarfları bastırılarak muhtarlar aracılığı ile dağıtılmıştır. ${ }^{106} 1955$ 'te inşasına başlanan okulun yapımı 1956' da tamamlanmış ve Ortaokulu eğitim-öğretime hazır duruma getirilmiştir. Aynı tarihlerde Gölcük İmam Hatip Ortaokul Yaptırma Derneği tarafında Gölcük’te de bir imam hatip ortaokulu yaptırılmıştır. ${ }^{107}$ 1955 'te İzmit'teki mevcut imam hatip ortaokullarından birisi tamir edilmiştir ve eğitim-öğreti hizmetlerine sunulmuştur.

\section{Sonuç}

Erken Cumhuriyet döneminden Demokrat Parti'nin son devri olan 1960 yılına kadar Kocaeli'nde en fazla okul yapılan yıllar 1950-1960 ara-

\footnotetext{
100 Karakök, “ Menderes Döneminde (1950-1960) Türkiye'de Eğitim”, s.94.

101 Türk Yolu, 15 Şubat 1955, No:5021.

102 Bizim Şehir, 14 Aralık 1954; Türk Yolu, 15 Aralık 1954.

103 Bizim Şehir, 29 Mart 1955.

104 Türk Yolu, 13 Mart 1955, No:5045.

105 Azim, 13 Şubat 1955, No: 452; Türk Yolu, 13 Şubat 1955, No: 5021.

106 Bizim Şehir, 16 Nisan 1955; Türk Yolu, 20-24 Aralı 1954; Bizim Şehir, 23 Aralık 1954.

107 Türk Yolu, 13 Mart 1955, No: 5045.
} 
sıdır. Özellikle devletin eğitim ve öğretime önem vermesi, okullaşma ve okuryazar oranının artmasında en önemli etkendir. Bilhassa her köyde okul yapılmış ve ortaokulu olmayan ilçe merkezi kalmamıştır. Ayrıca İzmit Lisesi dıșında Gölcük Lisesi'de yapılmıș ve vilâyetin önemli bir eksikliği giderilmiștir.

Netice itibarıyla, 1950'den itibaren Türkiye'de çok partili hayata geçiş sürecinde yaşanan sosyo-ekonomik ve toplumsal olaylar eğitime de yansımış ve DP iktidarı döneminde okul sayılarında büyük bir artışlar olmuştur. $\mathrm{Bu}$ bağlamda, Türkiye genelinde olduğu gibi Kocaeli'nde de okulların sayısı 3 kattan daha fazla bir şekilde büyümüş̧ür. Okul sayılarının artması ile eğitim daha kaliteli ve uygun bir hale gelmiş ve daha fazla kişinin okullardan faydalanmıştır. Bu da, Kocaeli'nde okuryazar oranının görece artmasını sağlamış ve okullar teknik ile bilimsel yönlerden desteklendiğinden eğitim ve öğretim faaliyetleri daha kaliteli hale gelmiştir.

\section{KAYNAKLAR}

\section{Süreli Yayınlar}

Azim Gazetesi

Bizim Şehir Gazetesi

Demokrat Kocaeli Gazetesi

Hürsöz Gazetesi

İstiklal Gazetesi

Türk Yolu Gazetesi

Yavuz İzmit Gazetesi

\section{Kitap ve Makaleler}

ARSLAN, Zehra, "Demokrat Parti Döneminde Trabzon'da Eğitim", Karadeniz İncelemeleri Dergisi, 11/11, 2015.

ATOM, Sinop, Sakarya, İzmit, Edirne, Tekirdağ İller, İstanbul 1958.

AVDAN, Fügen, Cumhuriyet Döneminde Kentleşme Sürecinde Planlama Deneyimi, 1930-1980 İzmit Planlarl, Kocaeli Üniversitesi Sosyal Bilimler Enstitüsü, Basılmamış Yüksek Lisans Tezi, Kocaeli 2009.

BiNici, Özden Senem, İzmit'te 1936-1966 Yıllarl Arasindaki Yapı Üretiminin Kentin Gelişimine Etkileri, Basılmamış Yüksek Lisans Tezi, Kocaeli Üniversitesi, Fen Bilimleri Enstitüsü, Kocaeli 2012.

Demokrat Parti Tüzük ve Programı, Ankara 1949.

DİGM, 1952 İstatistik Ylllığı, Ankara 1953.

DİGM, 1953 İstatistik Ylllığı, Ankara 1964.

DİGM, Meslek, Teknik ve Yükseköğretim (1950-51), Ankara 1952.

DİGM, Meslek, Teknik ve Yüksekögrretim (1952-53), Ankara 1954. 
DİGM, Meslek, Teknik ve Yükseköğretim (1953-60), Ankara 1963.

DİGM, Milli Ĕgitim Ístatistikleri İlköğretim (1950-1951), Ankara 1951.

DİGM, Milli Ĕgitim İstatistikleri İlköğretim (1951-1952), Ankara 1953.

DİGM, Milli Ĕgitim İstatistikleri İlköğretim (1953-1960), Ankara 1961.

DİGM, Milli Eğitim Ístatistikleri Ortaokul (1953-1961), Ankara 1963.

DİGM, Milli Eğitim İstatistikleri Ortaokul (1950-1951), Ankara 1952.

DİGM, Milli Eğitim Ístatistikleri Ortaokul 1951, Ankara.

DİGM, Ortaögretim İstatistikleri (1951-1952), Ankara 1952.

DİGM, Ortaögretim Ístatistikleri (1952-1953), Ankara 1957.

DİGM, Ortaöğretim İstatistikleri (1953-1960), Ankara 1963.

ESER, Gülşah, “Arifiye Köy Enstitüsü’nün Sapanca Gölü ve İzmit Körfezi’ndeki Balıkçılık Çalışmaları”, Uluslararası Gazi Akça Koca ve Kocaeli Tarihi Sempozyumu, C: I, (2015), Kocaeli.

KARAKÖK, Tunay, “Menderes Döneminde (1950-1960) Türkiye'de Eğitim”, Yükseköğretim ve Bilim Dergisi, 1 / 2, 2011.

KILIÇ, Emre, Demokrat Parti Dönemi Milli Eğitim Politikası, Basılmamış Yüksek Lisans Tezi, Anadolu Üniversitesi Sosyal Bilimler Enstitüsü, Eskişehir 2008.

Kocaeli 1967 İl Yıllı̆̆gl, Doğan Kardeş Matbaacılık, İzmit 1970.

ŞAHIN, Enis, Kronolojik Adapazarl Sakarya 1923-2004, Sakarya 2004.

ŞENYURT, Oya, “1923-1960 Yılları Arasında İzmit’te İnşa Edilen Yapılar ve Kentin Gelişimine Katkıları, Uluslararası Gazi Akça Koca ve Kocaeli Tarihi Sempozyuтu, C: I, (2015), Kocaeli.

ŞENYURT, Oya, "Bir Eğitimin İnşa Öyküsü ve Geçmişin Modern Mimarisi: "Lise Pavyonu"/İzmit Lisesi, Uluslararası Gazi Süleyman Paşa ve Kocaeli Tarihi Sempozyuтu, C: III, (2017), Kocaeli.

TANGÜLÜ, Zafer, Demokrat Parti Döneminin İlköğretim Politikaları (1950-1960), Basılmamış Yüksek Lisans Tezi, Fırat Üniversitesi Sosyal Bilimler Enstitüsü, Elazı̆̆ 2008.

TAŞDÖVEN, Zehra, Demokrat Parti Dönemi Ĕgitim Anlayışı (1950-1960), Basılmamış Yüksek Lisans Tezi, Adnan Menderes Üniversitesi Sosyal Bilimler Enstitüsü, Aydın 2013.

TUNÇ, Bilal, Demokrat Parti Döneminde Kocaeli (1950-1960), Basılmamış Doktora Tezi Sakarya Üniversitesi Sosyal Bilimler Enstitüsü, Sakarya 2016.

Yurt Ansiklopedisi İl İl Türkiye, Dünü, Bugünü, Yarını, C: VII, İstanbul 1983.

YÜCE, Rıfat, Kocaeli Tarih ve Rehberi, Kocaeli 1952. 
